\title{
LUAS PENGUNGKAPAN SUKARELA, ASIMETRI INFORMASI,DAN BIAYA MODAL EKUITAS
}

\author{
NOVITA ADELIANA DARMA \\ ANDRY IRWANTO
}

Fakultas Ekonomi dan Bisnis, Universitas Airlangga Surabaya

\begin{abstract}
Thisstudyexaminesthe effect ofvoluntary disclosureon thecost of equitycapitalwithinformation asymmetry as an intervening variablein manufacturing companieslistedin Indonesia Stock Exchangein the period of 20082012. The total populationofthis study were203companies. The research hypotheseswere tested usingpathanalysis model with unbalanced panel data. The study concludedthat thevoluntary disclosurehad indirect effecton thecost of equitycapitalby theinformation asymmetryas an intervening variable.
\end{abstract}

Keywords: Voluntary Disclosure, InformationAsymmetry, Cost Of EquityCapital

\begin{abstract}
ABSTRAK
Penelitian ini bertujuan untuk mengetahui pengaruh luas pengungkapan sukarela terhadap biaya modal ekuitas dengan asimetri informasi sebagai variabel intervening pada perusahaan manufaktur yang terdaftar di Bursa Efek Indonesia periode 2008-2012. Total populasi dari penelitian ini sebanyak 203 perusahaan. Hipotesis penelitian diuji dengan menggunakan model analisis jalur dengan menggunakana data unbalanced panel. Hasil penelitian menyimpulkan bahwa luas pengungkapan sukarela berpengaruh secara tidak langsung terhadap biaya modal ekuitas dengan asimetri informasi sebagai variabel intervening.

Kata Kunci: Luas Pengungkapan Sukarela, Asimetri Informasi, Biaya Modal Ekuitas
\end{abstract}




\section{PENDAHULUAN}

\section{Latar Belakang}

Di era persaingan industri yang semakin ketat,perusahaan dihadapkan pada suatu kondisi yang mendorong mereka untuk selalu berinovasi agar mampu terus tumbuh dan berkembang. Tentunya hal ini perlu diimbangi dengan ketersediaan dana yang memadai.Salah satu sarana yang dapat digunakan oleh perusahaan untuk memperoleh modal demi kelangsungan sebuah usaha adalah melalui pasar modal. Untuk melakukan aktivitas dipasar modal, para pelaku pasar mendasarkan keputusannya pada informasi yang mereka terima.Oleh karena itu, menjadi suatu keharusan bahwa informasi yang dihasilkan oleh suatu perusahaan merupakan informasi yang berguna sebagai pengambilan keputusan investasi dan ekonomi.

Laporan keuangan merupakan sarana bagi perusahaan untuk menyampaikan berbagai informasi dan pengukuran secara ekonomi mengenai sumber daya yang dimiliki serta kinerja kepada berbagai pihak yang memiliki kepentingan atas informasi tersebut. Informasi yang diungkapkan melalui laporan keuangan melalui keputusan ketua BAPEPAM No. Kep-134/BL/2006 yang dikutip oleh Prawesti (2009) dikelompokan menjadi dua yaitu pengungkapan wajib (mandatory disclosure) dan pengungkapan sukarela (voluntary disclosure).

Pada umumnya perusahaan hanya mengungkapkan informasi yang bersifat wajib (mandatory). Perusahaan akan memepertimbangkan biaya dan manfaat yang akan diperoleh ketika memutuskan untuk mengungkapkan secara penuh (full disclousure). Perusahaan hanya akan mengungkapkan informasi secara sukarela jika hal tersebut mampu memberikan manfaat yang lebih besar dibandingkan dengan biaya yang dikeluarkan (Eliot dan Jacobson, 1994). Hal ini yang seringkali menyebabkan timbulnya asimetri informasi karena perusahaan mempunyai informasi yang lebih banyak tentang perusahaan mereka daripada para pemegang saham atau pemangku kepentingan yang lain. Keadaan asimetri informasi yang tinggi menyebabkan pemegang saham tidak mempunyai informasi yang cukup untuk membantu mereka memprediksi tingkat resiko dan pengembalian yang akan diterima dari investasi yang telah dilakukan. Jika investor menilai suatu perusahaan beresiko tinggi berdasarkan laporan keuangan yang dihasilkan, maka nilai returninvestasi yang diharapkan oleh investor juga akan tinggi, sehingga menyebabkan tingginya biaya ekuitas (cost of equity capital).

Tingkat return tersebut terkait dengan tingkat resiko yang ditanggung oleh investor. Tingkat prediksi resiko tergantung pada seberapa luas informasi yang diungkapkan serta ketepatan informasi yang telah dilaporkan. Semakin luas dan tepat informasi yang dilaporkan kepada pemegang saham akan diikuti dengan penurunan prediksi resiko yang dihasilkan.Lang \& Lundholm (1996) memberikan hasil penelitian bahwa pengungkapan dapat mengurangi asimetri informasi. Keputusan investasi sangat tergantung pada mutu dan luas pengungkapan informasi yang disajikan dalam laporan keuangan tahunan. Pengungkapan dalam laporan keuangan ini diharapkan dapat melindungi para investor dari adanya asimetri informasi. Berkurangnya tingkat asimetri informasi juga akan 
mengurangi resiko estimasi, yang pada akhirnya dapat menurunkan biaya modal ekuitas.

Beberapa penelitian telah dilakukan untuk menguji pengaruh luas pengungkapan sukarela terhadap asimetri informasi, mereka diantaranya Diamond \& Verrecchia (1991), Welker (1995), Lang \& Lundhom (1996), dan Brown dan Hillegeist (2007). Hasil penelitian mereka menunjukan bahwa kebijakan pengungkapan yang lebih luas mampu mengurangi tingkat asimetri informasi suatu perusahaan. Peningkatan biaya modal ekuitas akibat adanya asimetri informasi juga telah dibuktikan oleh beberapa peneliti sepertiKomalasari (2001), Murwaningsari (2012), Purwanto (2012), Easley dan O'Hara (2004), Hughes et $a l$,. (2005), dan Verdi (2005). Hasil yang diperoleh dari penelitian-penelitian tersebut menunjukan terdapat hubungan positif signifikan antara asimetri informasi dengan cost of equity capital.

Penelitian ini penting dilakukan karena kajian teoritis tentang hubungan pengungkapan sukarela, asimetri informasi, dan biaya modal menunjukan pengungkapan sukarela mampu menurunkan asimetri informasi, dan pada akhirnya menyebabkan penurunan cost of equity capital. Munculnya ketidakkonsistenan hasil penelitian yang telah diuraikan sebelumnya memotivasi peneliti untuk menghasilkan temuan yang lebih luas dan mampu menjelaskan adanya ketidak konsistenan hasil dan kesimpulan tersebut. Penelitian ini mengacu pada penelitian yang dilakukan oleh Botosan (1997) yang menggunakan variabel pengungkapan sukarela. Perbedannya adalah variabel pengungkapan sukarela dalam penelitian ini merupakan pengungkapan sukarela (voluntary disclousure) dengan metode yang dikembangkan oleh Botosan (1997) yang telah disesuaikan dengan peraturan peraturan Bapepam Kep-134/BL/2006 yang dilakukan oleh Wardani (2012). Penelitian ini juga menggunakan variabel asimetri informasi sebagai variabel intervening yang mengacu pada penelitian Diamond \& Verrecchia (1991). Selain variabel-variabel tersebut, peneliti juga menggunakan variabel kontrol yaitu ukuran perusahaan dan leverage.

Berdasarkan uraian latar belakang diatas, maka rumusan masalah dalam penelitian ini adalah: apakah pengungkapan sukarela berpengaruh terhadap biaya modal ekuitas dengan asimetri informasi sebagai variabel intervening?. Berdasarkan permasalahan penelitian tersebut, tujuan penelitian ini adalah untuk mengetahui pengaruh pengungkapan sukarela terhadap biaya modal ekuitas dengan asimetri informasi sebagai variabel intervening.

Artikel ini terdiri dari beberapa bagian. Bagian kedua akan dibahas landasan teoritis. Bagian ketiga membahas tentang pengembangan hipotesis penelitian. Metodologi penelitian akan dibahas pada bagian keempat diikuti dengan hasil penelitian dan pembahasan pada bagian kelima. Kesimpulan, kelemahan, dan saran akan dibahas pada bagian keenam.

\section{TINJAUAN PUSTAKA}

\section{Teori Agensi (Agency Theory)}

Teori keagenan mendiskripsikan hubungan antara pemegang saham (shareholders) sebagai prinsipal dan manajemen sebagai agen. Jensen dan 
Meckling (1976) mengatakan bahwa hubungan keagenan adalah sebuah kontrak antara manajer (agent) dengan investor (principal). Konflik kepentingan antara prinsipal dan agenterjadi karena kemungkinan agen tidak selalu berbuat sesuai dengan kepentingan prinsipal. Agen yang memiliki kemampuan untuk beroperasi sendiri, cenderung lebih mementingkan kepentingan pribadi daripada kepentingan terbaik dari perusahaan. Dalam rangka memotivasi agen serta untuk menghindari munculnya konflik keagenan, maka prinsipal perlu merancang suatu kesepakatan kontrak.

\section{Teori Sinyal (Signallling Theory)}

Teori ini menjelaskan bahwa pemberian sinyal dilakukan oleh manajer untuk mengurangi asimetri informasi. Teori sinyal menekankankan kepada pentingnya informasi yang dikeluarkan oleh perusahaan terhadap keputusan investasi pihak diluar perusahan. Teori sinyal menjelaskan mengapa perusahaan mempunyai dorongan untuk memberikan informasi laporan keuangan pada pihak ekternal. Dorongan perusahaan untuk memberikan informasi kepada pihak eskternal adalah meningkatkan nilai perusahaan dan menunjukan bahwa perusahaan mempunyai nilai lebih atau keunggulan kompetitif dari perusahaan lain. Teori sinyal mengungkapkan tentang bagaimanan seharusnya sebuah perusahaan memberikan sinyal kepada pengguna laporan keuangan.

\section{Asimetri Informasi}

Asimetri informasi merupakan kondisi dimana manajer memiliki informasi yang lebih banyak, seperti informasi internal dan prospek perusahaan di masa depan dibandingkan pemegang saham dan stakeholder lainnya, sehingga beberapa konsekuensi tertentu hanya akan diketahui satu pihak tanpa diketahui pihak lain yang juga memerlukan informasi tersebut. Perspektif informasi asimetri mengimplikasikan bahwa manajer berupaya untuk mengurangi informasi asimetri guna memaksimumkan nilai perusahaan dengan cara yang dikehendakinya (Nuryatno dkk. (2007).

Menurut Scott (2006), terdapat dua macam bentuk asimetri informasi, yaitu: (1) Adverse selection, jenis asimetri informasi dimana salah satu pihak atau lebih yang terlibat dalam transaksi bisnis, atau transaksi yang potensial, memiliki keunggulan informasi dibandingkan dengan pihak lainnya; (2) Moral hazard, jenis asimetri informasi dimana salah satu pihak atau lebih yang terlibat dalam transaksi bisnis, atau transaksi yang potensial, dapat mengamati tindakan-tindakan mereka dalam penyelesaian transaksi tersebut, sementara pihak lainnya tidak.

\section{Pengungkapan Sukarela}

Mengacu pada surat keputusan BAPEPAM No.38/PM/1996,pengungkapan sukarela didefinisikan sebagai pengungkapan yang tidak diwajibkan oleh pemerintah, sehingga perusahaan bebas memilih jenis informasi yang akan diungkapkan oleh perusahaan. Pengungkapan sukarela juga merupakan salah satu cara untuk meningkatkan kredibilitas laporan keangan perusahaan dan untuk membantu investor dalam memahami strategi bisnis perusahaan (Healy dan Palepu, 1995). Sehingga dengan adanya pengungkapan 
sukarela para pemakai laporan keuangan akan semakin lengkap informasinya dalam memahami kegiatan operasional perusahaan publik. Selain itu, dengan adanya pengungkapkan sukarela makin menunjukan ketransparanan perusahaan. Menurut Eliot dan Jacobson (1994) Perusahaan hanya akan mengungkapkan informasi secara sukarela jika hal tersebut mampu memberikan manfaat yang lebih besar dibandingkan dengan biaya yang dikeluarkan.

\section{Biaya Modal Ekuitas (Cost of Equity Capital)}

Biaya modal ekuitasatau cost of equity capitaldidefinisikan sebagai return saham perusahaan yang diharapkan oleh investor ketika menginvestasikan uang mereka dalam perusahaan. Dengan kata lain, cost of equity capital dapat diidentifikasi sebagai tingkat return minimum yang diisyaratkan oleh penggunaan cost of equity (modal ekuitas) atas investasi. Biaya modal ekuitas sangat berkaitan dengan resiko investasi saham perusahaan. Pendapat lain juga menyebutkan bahwa biaya modal ekuitas mempunyai dua makna, tergantung dari sisi investor atau sisi perusahaan. Biaya modal ekuitas dari sisi investor adalah opportunity cost (biaya pengorbanan) dari dana yang ditanamkan investor pada suatu perusahan, atau dengan kata lain merupakan tingkat return yang diharapakna investor saat melakukan investasi pada perusahaan. Sedangkan pengertian biaya modal ekuitas dari sisi perusahaan adalah sama dengan yang diungkapkan oleh Cotner dan Harold (dalam Nuryatno dkk., 2007), yaitu biaya yang dikeluarkan oleh perusahaan untuk memperoleh sumber dana yang dibutuhkan.

\section{HIPOTESIS}

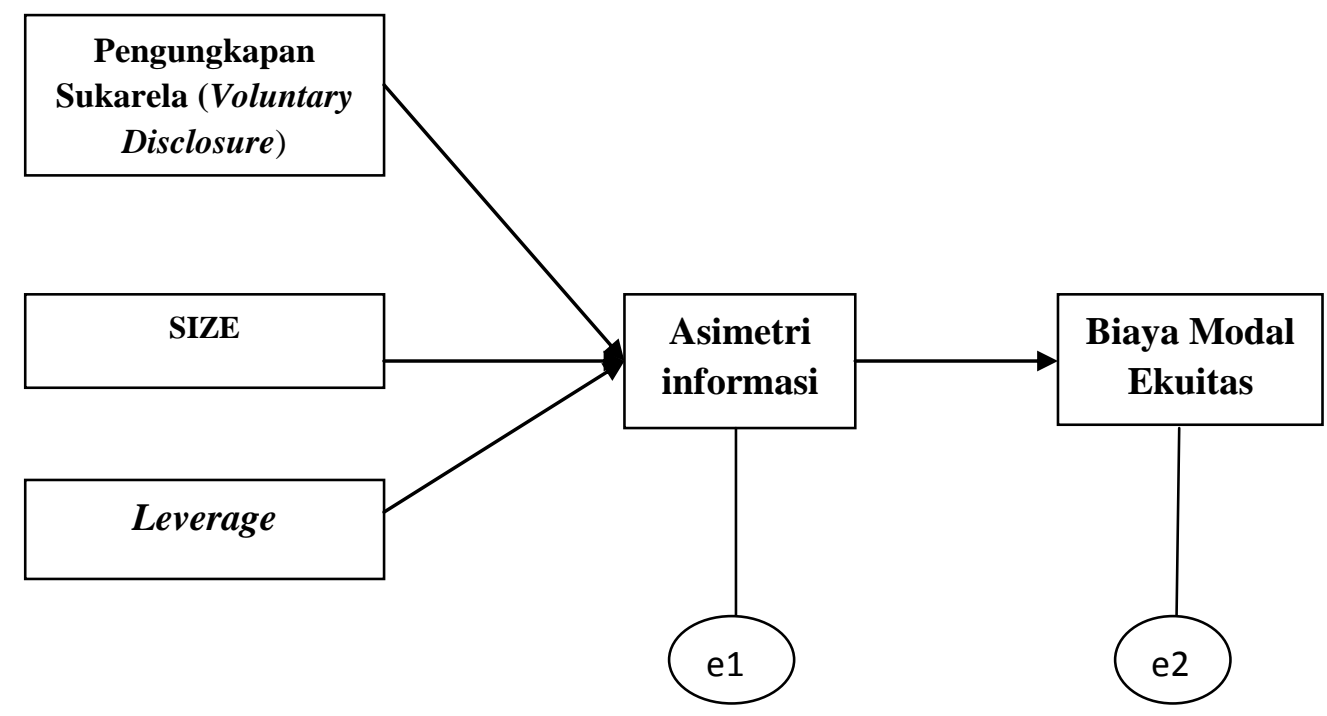

Gambar 3.1. Rerangka Konseptual 


\section{Perumusan Hipotesis}

Teori keagenan merupakan dasar dari perlunya pengungkapan laporan keuangan oleh manajemen kepada para pemegang saham. Dalam prakteknya, masalah keagenan muncul karena terdapat konflik kepentingan antara manajer (agent), pemegang saham (principal), dan stakeholder yang lain. Konflik kepentingan yang terjadi disebabkan adanya asimetri informasi antara manajer dan para pemangku kepentingan tersebut. Teori sinyal menjelaskan bahwa pemberian sinyal dilakukan oleh manajer untuk mengurangi asimetri informasi. Teori sinyal menekankankan kepada pentingnya informasi yang dikeluarkan oleh perusahaan terhadap keputusan investasi pihak diluar perusahaan. Pengungkapan informasi merupakan salah satu alat penting untuk mengatasi masalah keagenan antara agent dan principal. Semakin luas pengungkapan yang dilakukan oleh perusahaan, menunjukan bahwa tidak ada sesuatu yang disembunyikan, sehingga investor akan memiliki kepercayaan terhadap perusaahaan tersebut dan mengestimasikan resiko yang rendah. Ketika resiko yang diestimasi oleh investor rendah, maka tingkat pengembalian yang diharapkan juga akan rendah yang pada akhirnya menurunkan biaya modal ekuitas.

Diamond \& Verrecchia (1991) menemukan bahwa dengan mengungkapkan informasi privat maka tuntutan investor terhadap kompensasi menurun karena biaya transaksi turun, yang digambarkan oleh nilai bid-ask spread, dan pada akhirnya biaya modal ekuitasjuga akan menurun. Anggraeni (2010), yang melakukan penelitian tentang pengaruh pengungkapan sukarela terhadap cost of equity capital dengan asimetri informasi sebagai variabel intervening, menemukan bahwa pengungkapan sukarela dapat berpengaruh secara langsung ke cost of equity capital dan dapat juga berpengaruh secara tidak langsung yaitu dari pengungkapan sukarela ke asimetri informasi (sebagai intervening) lalu ke cost of equity capital. Peneliti lain seperti Putri (2013) juga menunjukkan bahwa pengungkapan sukarela berpengaruh secara langsung maupun tidak langsung dengan asimetri informasi sebagai variabel intervening. Berdasarkan uraian diatas, maka hipotesis yang dapat disusun adalah sebagai berikut:

$\mathrm{H}_{\mathrm{a}}$ : Pengungkapan sukarela berpengaruh negatif terhadap biaya modal ekuitas dengan asimetri informasi sebagai variabel intervening.

\section{METODE PENELITIAN}

\section{Populasi dan Metode Pengumpulan Data}

Populasi penelitian ini adalah seluruh perusahaan manufaktur yang terdaftar di Bursa Efek Indonesia periode 2008-2012 yaitu sebanyak 136 perusahaan manufaktur. Pemilihan populasi dalam penelitian ini menggunakan metode sensus, yaitu meneliti seluruh elemen populasi. Perusahaan manufaktur yang menjadi populasi sasaran adalah perusahaan manufaktur yang memiliki kriteria sebagai berikut: (a) Perusahaan tidak pernah delisting dari Bursa Efek Indonesia, tidak melakukan penggabungan usaha, dan tidak berubah status sektor industrinya, (b) Perusahaan manufaktur yang mempublikasikan laporan tahunan (annual report) minimal dua tahun selama periode 2008-2012, (c) 
Mempublikasikan laporan tahunan dengan satuan nilai rupiah, (d) Perusahaan tidak memiliki nilai cost of equity capital negatif, dan (e) Data yang tersedia lengkap selama periode 2008-2012.

Penelitian ini menggunakan data sekunder berupa annual report emiten manufaktur yang listing di Bursa Efek Indonesia selama periode 2008-2012 yang diperoleh dari situs resmi Bursa Efek Indonesia (BEI) pada http://www.idx.co.iddan data-data yang diperlukan lainnya pada Indonesian Capital Market Electronic Library (ICaMEL)dan situs resmi Bank Indonesia pada www.bi.go.id. Metode yang digunakan dalam pemgumpulan data tersebut menggunakan metode dokumentasi.

\section{Definisi Operasional Variabel dan Pengukuran}

1. Variabel Independen

a. Pengungkapan Sukarela

Pengungkapan sukarela dalam penelitian ini diukur dengan menggunakan indeks pengungkapan sukarela dengan metode yang dikembangkan oleh Botosan (1997) yang telah disesuaikan dengan peraturan pengganti KEP-38/PM/1996 yaitu peraturan Bapepam Kep134/BL/2006 yang dilakukan oleh Wardani (2012). Jika satu item pengungkapan sukarela terpenuhi, maka diberi nilai 1 (satu) dan 0 (nol) jika sebaliknya. Rumus untuk menghitung indeks pengungkapan adalah sebagai berikut:

$$
\text { Indeks Pengungkapan }_{i t}=\frac{n}{k}
$$

\section{b. Ukuran Perusahaan}

Perhitungan ukuran perusahaanmengacu pada penelitian yang dilakukan Fama dan French (1993), yaitu log natural ( $L n)$ dari nilai pasar saham pada akhir tahun degan rumus sebagai berikut:

$$
\text { Size }_{i t}=\ln (\text { jumlah saham beredar } \mathrm{x} \text { closing price })
$$

\section{c. Leverage}

Leverage perusahaan dihitung dengan menggunakan debt to total asset ratio (DAR) yang diperoleh dengan cara membagi total hutang perusahaan dengan total aset akhir tahun:

$$
\text { DAR }_{\text {it }}=\frac{\text { Total Utang }}{\text { Total Aset }}
$$




\section{Variabel Dependent}

\section{a. Biaya Modal Ekuitas}

Biaya modal ekuitas di ukur dengan menggunakan pendekatan Capital Asset Pricing Model (CAPM) dengan rumus CAPM adalah sebagai berikut:

$$
\mathrm{COC}_{\mathrm{it}}=\mathbf{R}_{\mathrm{ft}}+\boldsymbol{\beta}_{\mathrm{i}}\left(\mathbf{R}_{\mathrm{mt}}-\mathbf{R}_{\mathrm{ft}}\right)
$$

Dimana:

$\mathrm{COC}_{\mathrm{it}}=$ Biaya modal ekuitas (cost of capital) perusahaan i pada tahun $\mathrm{t}$

$\mathrm{R}_{\mathrm{ft}} \quad=$ Return bebas resiko yang diproksikan dengan tingkat bunga SBI rata-rata 1 bulan

$\beta_{\mathrm{i}} \quad=$ Risiko sistemastis untuk setiap saham perusahaan $\mathrm{i}$

$\mathrm{R}_{\mathrm{mt}} \quad=$ Return pasar yang diperoleh dari IHSG periode $\mathrm{t}$ ditambah IHSG periode $\mathrm{t}-1$ dibagi IHSG periode $\mathrm{t}-1$

Perhitungan $\beta_{\mathrm{i}}$ (risiko sistematis) dalam penelitian ini menggunakan regresi market model dengan periode estimasi selama 100 hari sebelum event windows(tanggal publikasi laporan keuangan tahunan). Persamaannya adalah sebagai berikut:

Dimana:

$$
\mathbf{R}_{\mathrm{it}}=\alpha_{\mathrm{i}}+\beta_{\mathrm{i}} \mathbf{R}_{\mathrm{mt}}+\varepsilon_{\mathrm{i}}
$$

$\mathrm{R}_{\mathrm{it}} \quad=$ return saham harian perusahaan pada periode pengamatan $\mathrm{t}$

$\mathrm{R}_{\mathrm{mt}} \quad=$ return pasar harian pada periode pengamatan $\mathrm{t}$

$\beta_{\mathrm{i}} \quad=$ beta saham perusahaan $\mathrm{i}$

\section{b. Asimetri Informasi}

Pengukuran asimetri informasi ini menggunakan relativebid-ask spread berdasarkan Komalasari dan Baridwan (2001) yang dilakukan sebagai berikut:

$$
\operatorname{SPREAD}_{\mathrm{it}}=\left[\left(\operatorname{ask}_{\mathrm{i}, \mathrm{t}}-\text { bid }_{\mathrm{i}, \mathrm{t}}\right) /\left(\left(\mathbf{a s k}_{\mathrm{i}, \mathrm{t}}+\text { bid }_{\mathrm{i} . \mathrm{t}}\right) / 2\right)\right] \times 100 \%
$$

\section{Dimana:}

$\mathrm{ASK}_{\mathrm{i}, \mathrm{t}} \quad=$ harga ask (harga penawaran) terendah saham perusahaan i yang terjadi pada hari $\mathrm{t}$

$\mathrm{BID}_{\mathrm{i}, \mathrm{t}} \quad=$ harga bid (harga permintaan) tertinggi saham perusahaan i yang terjadi pada hari $\mathrm{t}$

Ask price dan bid price yang digunakan adalah \pm 3 hari disekitar tanggal publikasi laporan keuangan dan pada tanggal publikasi laporan keuangan $(\mathrm{t}-3, \mathrm{t}, \mathrm{t}+3)$. 


\section{Teknik Analisis Data}

Sehubungan dengan penggunaan metode regresi berganda, maka penelitian ini perlu melakukan pengujian asumsi klasik diantaranya: (1) uji normalitas; (2) uji multikolonieritas; (3) uji heteroskedastisitas, (4) uji autokorelasi. Pengujian atas hipotesis menggunakan analisis jalur (Path Analysis) dengan struktur sebagai berikut:

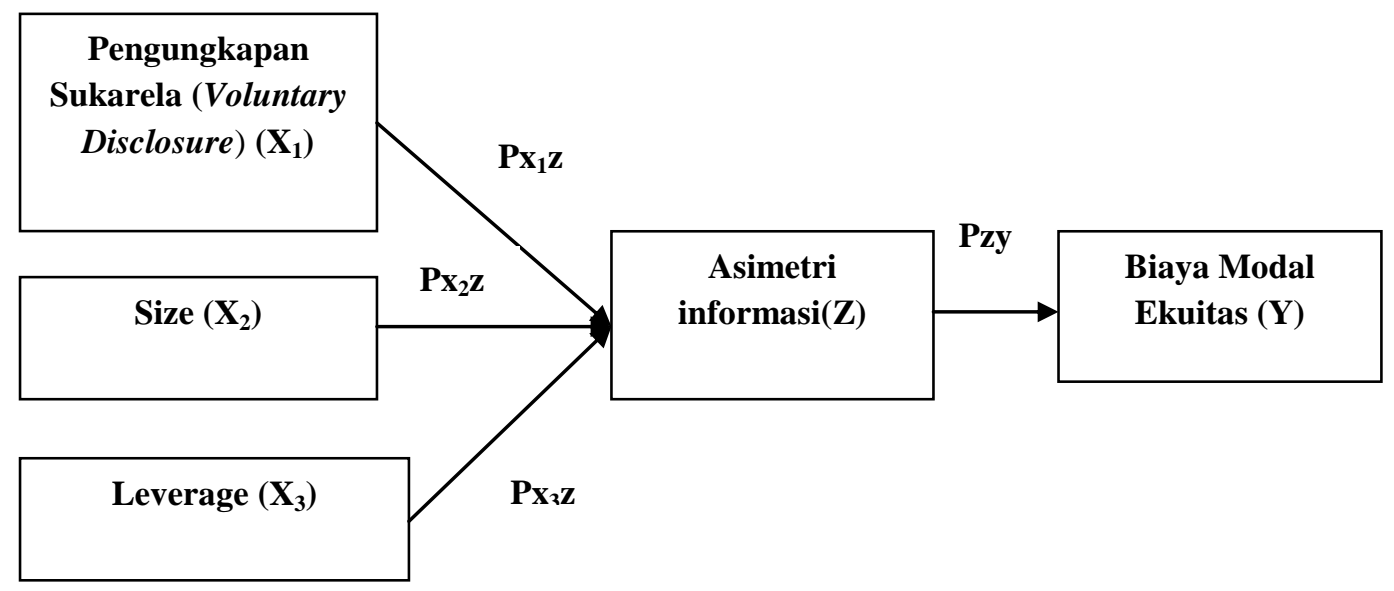

Berdasarkan gambar di atas dapat dijelaskan bahwa pengungkapan sukarela merupakan variabel eksogen, asimetri informasi dan biaya modal ekuitas merupakan variabel endogen. Ukuran perusahaan dan leverage berfungsi sebagai variabel kontrol. Persamaan struktural yang dapat dibentuk adalah:

1. $Z=P x_{1} z X_{1}+P x_{2} z X_{2}+P x_{3} z X_{3}+e$

2. $Y=P x_{1} y X_{1}+P x_{2} y X_{2}+P x_{3} y X_{3}+P z y Z+e$

Dimana:

$\mathrm{Px}_{1} \mathrm{zX}_{1} \quad=$ Koefisien jalur dari pengungkapan sukarela ke asimetri informasi

$\mathrm{Px}_{2} \mathrm{ZX}_{2} \quad=$ Koefisien jalur dari ukuran perusahaan ke asimetri informasi

$\mathrm{Px}_{3} \mathrm{ZX}_{3} \quad=$ Koefisien jalur dari leverage ke asimetri informasi

$\mathrm{Px}_{1} \mathrm{yX}_{1} \quad=$ Koefisien jalur dari pengungkapan sukarela ke cost of equity capital

$\mathrm{Px}_{2} \mathrm{yX}_{2}=$ Koefisien jalur dari ukuran perusahaan ke cost of equity capital $\mathrm{Px}_{3} \mathrm{yX}_{3}=$ Koefisien jalur dari leverage ke cost of equity capital

PzyZ = Koefisien jalur dari asimetri informasi ke cost of equity capital 


\section{ANALISIS DAN PEMBAHASAN}

\section{Statistik Deskriptif}

\begin{tabular}{|l|r|r|r|r|r|}
\hline & $\mathrm{N}$ & Minimum & Maximum & Mean & Std. Deviation \\
\hline COC & 203 &, 00 & 1,14 &, 1836 &, 20275 \\
Spread & 203 &, 0016 &, 8732 &, 036775 &, 0985693 \\
Voluntary & 203 &, 07 &, 48 &, 2684 &, 08548 \\
Leverage & 203 &, 07 & 1,57 &, 4557 &, 21434 \\
Size & 203 & 23,84 & 33,94 & 28,0394 & 2,36436 \\
Valid N (listwise) & 203 & & & & \\
\hline
\end{tabular}

\section{Uji Asumsi Klasik}

1. Uji normalitas

Berdasarkan hasil pada gambar normal probability plotuntuk kedua model diketahui bahwa plot dari nilai residual telah menyebar di sekitar garis diagonal yang menandakan bahwa model regresi terhadap asimetri informasi dan biaya moal ekuitas telah memenuhi asumsi normalitas.

2. Uji Multikolonieritas

Hasil pengolahan data statistik diperoleh tabel pengujian multikolonieritas sebagai berikut:

Tabel 5.1 Uji Multikolonieritas

\begin{tabular}{|c|l|c|c|}
\hline Model Regresi & \multicolumn{1}{|c|}{ Variabel } & VIF & Tolerance \\
\hline \multirow{2}{*}{$\begin{array}{c}\text { Model 1 } \\
\text { Asimetri } \\
\text { informasi) }\end{array}$} & Pengungkapan Sukarela & 1,326 & 0,754 \\
\cline { 2 - 4 } & Size & 1,048 & 0,955 \\
\cline { 2 - 4 } & Leverage & 1,381 & 0,724 \\
\hline \multirow{3}{*}{$\begin{array}{c}\text { Model 2 } \\
\text { Biaya modal } \\
\text { ekuitas) }\end{array}$} & Pengungkapan Sukarela & 1,043 & 0,959 \\
\cline { 2 - 4 } & Size & 1,356 & 0,737 \\
\cline { 2 - 4 } & Leverage & 1,059 & 0,944 \\
\cline { 2 - 4 } & Asimetri Informasi & 1,399 & 0,715 \\
\hline
\end{tabular}

Sumber: hasil olahan SPSS, 2014

Berdasarkan tabel di atas diketahui nilai VIF untuk semua variabel bebas lebih kecil dari dari 10 begitu juga untuk nilai tolerance yang lebih besar dari 0,1. Dengan demikian dapat disimpulkan bahwa kedua model regresi telah memenuhi asumsi nonmultikolonieritas. 


\section{Uji Heteroskedastisitas}

Berdasarkan hasil grafik scatterplot dapat dilihat bahwa titik-titik menyebar secara acak dan tersebar baik diatas maupun dibawah angka 0 pada sumbu Y dan dikanan serta kiri pada sumbu X. Dengan demikian dapat disimpulkan bahwa kedua model regresi tidak terjadi gejala heteroskedastisitas atau dengan kata lain telah memenuhi asumsi non heteroskedastisitas.

4. Uji Autokorelasi

Tbel 5.2 Uji Autokorelasi

\begin{tabular}{|c|c|c|c|}
\hline Model Regresi & $\begin{array}{c}\text { Batas } \\
\text { Bawah }\end{array}$ & $\begin{array}{l}\text { Durbin } \\
\text { Watson }\end{array}$ & Batas Atas \\
\hline Model 1 & \multirow{2}{*}{-2} & 1,865 & \multirow{2}{*}{2} \\
\hline Model 2 & & 1,011 & \\
\hline
\end{tabular}

Sumber: hasil olahan SPSS, 2014

Dari Tabel 5.2 dapat dilihat bahwa nilai Durbin-Watson untuk model regresi 1sebesar 1,865dan model regresi 2 sebesar 1,011. Nilai DurbinWatson berada di rentang -2 sampai dengan +2 , sehingga dalam kedua model regresi ini tidak terjadi gejala autokorelasi.

\section{Hasil Uji Hipotesis dan Pembahasan}

Tabel 5.3 Hasil Koefisien Jalur

\begin{tabular}{|l|c|c|c|}
\hline \multicolumn{1}{|c|}{ Path } & Std. Koefisien & $\begin{array}{c}\text { Nilai Sig. } \\
(<\mathbf{0 , 0 5})\end{array}$ & Keterangan \\
\hline PS $\rightarrow$ AI & $-0,136$ & 0,036 & Signifikan \\
\hline AI $\rightarrow$ COC & $-0,206$ & 0,004 & Signifikan \\
\hline
\end{tabular}

Sumber: hasil olah SPSS, 2014

Berdasarkan hasil uji hipotesis pada tabel 5.3, dapat dilihat bahwa pengungkapan sukarela berpengaruh negatif signifikan terhadap asimetri informasi sebesar 0,036 dan asimetri informasi berpengaruh negatif signifikan terhadap biaya modal ekuitas sebesar 0,004. Arah koefisien hubungan tidak langsung menunjukan arah yang positif yaitu sebesar $0,028(-0,136 \mathrm{x}-0,206)$. Oleh karena itu, Hipotesis yang menyatakan bahwa luas pengungkapan sukarela berpengaruh negatif terhadap biaya modal ekuitas melalui asimetri informasi ditolak.

Arah koefisien yang negatif antara luas pengungkapan sukarela terhadap asimetri informasi menunjukan bahwa jika pengungkapan sukarela yang dilaporkan semakin luas maka asimetri informasi akan menurun. Semakin tinggi 
tingkat pengungkapan sukarela, maka semakin banyak informasi yang diungkapkan oleh perusahaan sehingga menunjukan tidak ada sesuatu yang disembunyikan pada laporan tahunan perusahaan. Tingkat pengungkapan yang tinggi mengimplikasikan rendahnya asimetri informasi antara pihak manajemen dengan investor dan para pemangku kepentingan lainnya.

Selanjutnya, arah koefisien yang negatif antara asimetri informasi terhadap biaya modal ekuitas menunjukan bahwa jika asimetri informasi yang terjadi disuatu perusahaan meningkat maka biaya modal ekuitas akan menurun. Teori keagenan, meningkatkan kualitas laporan publik dapat mengurangi asimetri informasi antar investor dan juga menurunkan biaya modal ekuitas. Namun Lambert et al., (2011) pada penelitiannya menyatakan bahwa pada pasar persaingan sempurna, efek yang terjadi pada cost of equity capital terjadi sematasemata karena dengan meningkatnya kualitas informasi publik dapat meningkatkan penilaian atas presisi rata-rata dari informasi yang dimiliki investor, bukan karena mengurangi asimetri informasi. Bursa Efek Indonesia (BEI)merupakan contoh pasar persaingan sempurna dimana investor bertindak sebagai price taker. Sehingga diperkirakan peningkatan asimetri informasi di dalam BEI dapat menurunkan biaya modal ekuitas karena terjadinya perubahan struktur informasi tersebut mampu meningkatkan penilaian terhadap presisi ratarata investor.

\section{KESIMPULAN, KETERBATASAN, DAN SARAN}

\section{Kesimpulan}

Berdasarkan pengujian hipotesis yang dilakukan, maka hasil penelitian dapat disimpulkan sebagai berikut:

1. luas pengungkapan sukarela berpengaruh negatif signifikan terhadap biaya modal ekuitas. Semakin tinggi tingkat pengungkapan sukarela maka semakin banyak informasi yang diungkapkan oleh perusahaan dan menunjukkan tidak ada sesuatu yang disembunyikan pada laporan tahunan perusahaan sehingga asimetri yang terjadi antara manajemen dengan investor juga akan menurun.

2. Asimetri informasi berpengaruh negatif signifikan terhadap biaya modal ekuitas. Semakin tinggi asimetri informasi suatu perusahaan maka cost of equity capital akan menurun. Diperkirakan terjadinya perubahan struktur informasi tersebut mampu meningkatkan penilaian terhadap presisi rata-rata investor atas laporan keuangan sehingga biaya ekuitas menurun.

Asimetri informasi kemudian terbukti dapat memediasi hubungan antara luas pengungkapan sukarela terhadap biaya modal ekuitas dan hubungan yang terjadi merupakan hubungan tidak langsung.

\section{Keterbatasan}

Terdapat beberapa keterbatasan dalam penelitian ini, yaitu:

1. Penelitian ini hanya menggunakan satu jenis industri yang terdaftar di Bursa Efek Indonesia yaitu industri manufaktur sehingga sampel yang diperoleh 
sangat terbatas dan generalisasi hasil temuan serta rekomendasi penelitian ini kurang mampu diberlakukan diluar industri manufaktur.

2. Masih terdapat unsur subjektivitas dalam mengukur luas pengungkapan sukarela, karena dalam melakukan penilaian peneliti berdasarkan pada interpretasi atas kandungan informasi laporan tahunan yang memungkinkan terjadinya perbedaan penilaian untuk setiap perusahaan.

\section{Saran}

1. Penambahan sektor industri lain agar hasil penelitian dapat digeneralisasi untuk semua perusahaan mengingat tujuan dari penelitian kuantitatif adalah mampu memberikan hasil penelitian yang dapat digeneralisai untuk semua sampel.

2. Peneliti selanjutnya dapat mempertimbangkan penggunaan skor rata-rata (mean score) dalam mengukur luas pengungkapan sukarela. Mean score dapat diperoleh dengan melibatkan beberapa peneliti dalam penilaian laporan tahunan untuk menentukan seberapa luas pengungkapan sukarela yang dilakukan oleh suatu perusahaan.

\section{DAFTAR PUSTAKA}

Anggraeni, M. D. (2010). Pengaruh pengungkapan sukarela pada cost of equity capital dengan asimteri informasi sebagai intervening variabel. Trikonomika, 9(1), 62-71.

Botosan, C. A. (1997). Disclosure level and the cost of equity-capital. The Accounting Review, 72, 323-349.

Diamond, D.W., dan Verrecchia, Robert E. (1991). Disclosure, liquidity, and the cost of capital. The Journal of Finance, XLVI(4), 1325-1359.

Easley, D., and O'Hara, M. (2004). Information and the cost of capital. Journal of Finance, 59, 1553-1583.

Elliot, R. G. and Peter D. Jacobson. (1994). Cost and Benefit of Business Information Disclosure. Accounting Horizon, 8, 80-96.

Fama, E.F., and French, K.R. (1993). Common risk factors in the returns on stocks and bonds. Journal of Financial Economics, 33, 3-56.

Healy, P., and Palepu, K. (1995). The challenges of investor communications: The case of CUC international, Inc. Journal of Financial Economics, 38, 111141.

Hughes, J., Liu, J., and Liu, J. (2005). Information, diversification, and the cost of capital. The Accounting Review, 82, 705-729.

Jensen, M.C and Meckling, W.H. (1976). Theory of the firm: managerials behavior, agency cost and ownership structure. Journal Of Financial Economics, 3, 305-360.

Komalasari dan Baridwan. (2001). Asimetri informasi dan cost of equity capital. Jurnal Riset Akuntansi Indonesia, 4(1), 64-81. 
Lang, M., and R. Lundhol. (1993). Cross-Sectional Determinants of Analyst Ratings of Corporate Disclosures. Journal of Accounting Research, Autumn, 246-271.

Lambert, R., Leuz, C., and Verrechia, R. E. (2011). Information Asymmetry, Information Precision, and the Cost of Capital. Retrieved November 18, 2014, fromhttp://www.ssrn.com.

Nuryatno, M., Nazir, N., dan Rahmayanti, M. (2007). Hubungan antara pengungkapan, informasi asimetri, dan biaya modal. Jurnal Informasi, Perpajakan, Akuntansi dan Keuangan Publik, 2(1), 09-26.

Scott, W.R. (2003). Financial Accounting Theory. New York: Prentice Hall.

Stoll, H. (1989). The pricing of security dealer services: an empirical study of NASDAQ stock. Journal of finance, 33, 1153-1172.

Verdi, Rodrigo. S. (2005). Information environtment and the cost of equity capital. Retrieved February 17, 2014, from http://www.ssrn.com

Wardani, Puruwita. Rr. (2012). Faktor-faktor yang mempengaruhi luas pengungkapan sukarela. Jurnal Akuntansi dan Keuangan, 14(1), 1-15.

Welker, M. (1995). Disclosure policy, information asimmetry, and liquidity in equity market. Contemporary Accounting Research, 11, 801-827. 